\title{
Current Situation and Measures to Improve the Ideological and Political Education among Students in Higher Vocational Institutions
}

\author{
Xianzhen Li* \\ Jiangmen Traditional Chinese Medicine Vocational College, Jiangmen City, China
}

\begin{abstract}
College students are the foundation for China's long-term development plan. The ideological and political education for higher vocational institution students is particularly important. This paper firstly analyzes the current situation of ideological and political education for students in higher vocational institutions. In addition to that, following the understanding of the main problems existing in this education, this paper provides a comprehensive analysis and systematic measures for improving the ideological and political education among students in higher vocational institutions.
\end{abstract}

Keywords: Higher vocational education; Ideological and political; Countermeasures

Publication date: May, 2021; Publication online: 31 May, 2021

*Corresponding author: Xianzhen Li, 1074029157@qq.com

\section{Introduction}

Higher vocational institutions are important elements of the higher education in China. The ultimate goal of the development of higher vocational schools is to develop students with strong practical skills. However, one of its main issue is that these schools have to improve the ideological and political education levels in order to nurture highly skilled students with excellent qualifications. Therefore, higher vocational institutions should diligently perform their duties to improve the methods of student training, enhance the ideological and political education accordingly, and set this education as the ultimate goal in training students. Based on current analyses of ideological and political education among college students in China, this paper mainly expounds the problems existing in this education among the same group of students in China; thus, putting forward a more precise training policy of ideological and political education.
2 Analysis on the Current Standards of Ideological and Political Education among Students in Higher Vocational Institutions

The main issues that colleges and universities need to resolve are identifying proper methods to encourage and improve the ideological and political education as well as to set proper principles for managing these institutions. The higher vocational institutions in China emphasize on ideological and political education. Hence, constant efforts were made to improve in this aspect. However, in the ideological learning and teaching system, it still lacks professional experience which is more common in this field.

\subsection{Systematic analysis of the current education} standards of ideological and political courses in higher vocational institutions in China

Based on current systematic analysis, it is found that China's higher vocational institutions offer courses related to ideology and politics, such as "Situation and Policy" as well as other relevant courses. These courses have their own practical purposes, whereby it is helpful for students to 
develop a precise view of science and values, as well as to promote the long-term development of students. The education authorities in China have placed huge emphasis on the ideological and political education in colleges and universities, in addition to updating these courses accordingly with the current era while basing on the fundamental principles. This effort not only helps to improve the quality of the ideological and political education courses, but also plays a role in promoting educational achievements. Based on a systematic analysis, some scholars have conducted investigations and combined it with their own teaching experiences. They have found that some colleges and universities inevitably face a series of problems in conducting ideological and political education.

Under the current conditions, the overall educational development requirements of higher vocational institutions are generally consistent with the outline put forward by the Ministry of Education. In regard to the students' attributes, the college have scheduled sufficient time for ideological and political courses and are usually taught in combined classes with large number of students. This method minimizes the teaching hours. On the other hand, in view of poor time and place allocation, teaching methods need to be improvised to provide detailed information for students to learn effectively. It is also difficult for ideological and political teachers to pique students' interest in learning via a scripted way. Teachers often make every effort to teach a class, but many students are just indifferent to learning as if they were talking to a wall.

By referring to relevant materials, documents, and a systematic analysis to understand ideological and political education courses of modern-day vocational college students, it is found that most students believe that these courses play a very important role. The ideological and political education courses are beneficial for students to cultivate moral values and to understand records or policies issued by the state in addition to better publicize the cultural morality of the country. This education also plays an important role in the future development of college students. Contrary to their beliefs, students show a completely different behavior when attending such courses. Compared to the main courses, ideological and political education course is considered unimportant with monotonous content. Most of the higher vocational institution students attend these classes just to acquire credits. Only a few students are really interested in such courses.

\subsection{Relationship between the Party and League organizations and higher vocational institution students}

The Party and League organizations in higher vocational institutions can effectively promote the development of ideological and political education among college students. The Central Committee of the Communist Party of China (CPC) made the following decisions whereby it is necessary to take effective measures to play the role of the party at political and organizational levels. At the same time, to improve the structure of the ideological and political organization, a combination of its own advantages and characteristics in order to innovate and develop continuously is crucial. This can play a role in ensuring that the party organization becomes the foundation of students' ideological and political education. According to reliable data, more than $99 \%$ of the students in higher vocational institutions are League members, and more than 3\% of them are Party members. ${ }^{[1]}$ It can be seen from this that there is an extremely close relationship between the educational committee of the Party and the ideological and political standards of college students.

\section{A Comprehensive Analysis of Problems Existing in the Ideological and Political Education for Students in Higher Vocational Institutions}

\subsection{Inadequate overall quality evaluation system}

At present, the ideological and political education in higher vocational institutions is in the early stages of development. Therefore, there are no proper systems for fundamental elements, such as 
the moral quality evaluation system. The current comprehensive quality evaluation system emphasizes on evaluating students' performances, attendance rate and other indicators, but it is unable to reflect upon the overall quality of students. This kind of evaluations do not focus on students' independent qualities and they lead to the neglect of the practical aspect that the students do in their daily life. According to investigations, China's higher vocational education should regard students' development as the ultimate goal, instill a sense of responsibility and legal concepts among the students and to integrate the education with the current development trends. This is to improve and enhance the development of ideological and political education. ${ }^{[2]}$

\subsection{Neglect of ideological education in emphasis on vocational skills development}

Based on the comprehensive analysis of the skills development in vocational colleges for many years, it is found that most colleges only focus on the development of vocational skills singly. In the actual education process, they do not pay attention to the development of professional ethics. Based on the management of higher vocational institutions, it is understandable to emphasize on the training of vocational skills. However, ideological and political education level among college students should also be enhanced. In regard to that, the development of vocational skills as well as ideological and political education are in fact complementary to each other. Only with this knowledge, students will be able to establish a proper outlook in life. Therefore, colleges and universities should consolidate the existing issue to deal with the situation.

\subsection{Prejudice of the society on higher vocational institution students and their lack of confidence}

Parents that are influenced by the traditional educational concept, believes that undergraduate education is extremely important and is regarded as the only type of higher education. As a result, parents are reluctant to enroll their children in vocational institutions. Based on this concept, people think that vocational college students are just ordinary workers, and they would not have good opportunities for advancement. Civil employers also have a certain perception about vocational college students. Hence, this gives rise to the assumption that students trained in vocational colleges are unable to meet the current development needs. With these conceptions, some students develop inferiority complex, and it becomes a psychological burden to them; thus, losing the motivation to strife. ${ }^{[3]}$

4 Effective Measures for Improving the Ideological and Political Education among Students in Higher Vocational Institutions

\subsection{Changing the concept of talent training and} enhance quality-oriented education

In today's society, it is important to ensure that the training approach to vocational education focuses on employment-oriented aspects with service as basis. Colleges and universities should not only emphasize on the cultivation of students' vocational skills, but also to focus on the teaching aspects in their courses. Ideological and political quality will affect the long-term development of vocational college students, thereby influencing this generation to different degrees.

4.2 Strengthen the organization and management and improve the overall quality of the political education team

Effective measures should be taken to improve the overall quality of the education team. Higher vocational institutions should strengthen their team of teachers and improve their competence by establishing organized work plans, as well as making incentive measures to promote the development of teachers. In addition to that, higher vocational institutions should also introduce professional instructors according to specific development needs of the school. It is necessary to strengthen the ideological and political education team in higher vocational institutions by implementing elimination systems in combination 
with specific needs based on current situations. In regard to that, it is not only conducive to the dynamic management of the team of teachers, but also enables them to form a sense of responsibility and organization, which are extremely important in the growth of the whole team.

\subsection{Emphasis on students' development in the context of cultivating excellent virtues and continuous improvement based on traditions}

According to the analysis of the ideological status quo among students in higher vocational education, it is found that ideological and political teachers emphasize the following development requirements. To broaden the platform of ideological and political education, students' development should be the main focus while education development acts as guidance. Firstly, colleges can make use of multimedia to publicize contents which are related to fundamental values, in order to bridge the gap between students and teachers as well as to better understand the student's daily life. Secondly, through in-depth communication with students, colleges may be able to timely recognize their psychological needs, problems, or doubts in the process of maturing, to help students in ways to solve or relieve their psychological pressure.

\section{Conclusion}

By explaining the present situation of ideological and political education among students in higher vocational institutions, this paper made a deep analysis in order to understand a series of development problems involved in the process of ideological and political education among students in higher vocational institutions. Based on this, specific measures were suggested, in hope to provide some reference for the future development of ideological and political education.

\section{Disclosure statement}

The author discloses no conflicts of interest.

\section{References}

[1]Chen, Y(2016). Analysis and suggestions on the current situation of ideological and political education of students in higher vocational colleges. Journal of Hubei University of Economics (Humanities and Social Sciences Edition), 13(02):158-159.

[2] Li, D(2014). Research on ideological and political education of students in higher vocational colleges. Henan: Master's Dissertation of Henan University of Technology.

[3] Wang, S., Yang, Y., Yang, H(2015). A review of research on ideological and political education under big data. University Education Science, (03):112-117. 